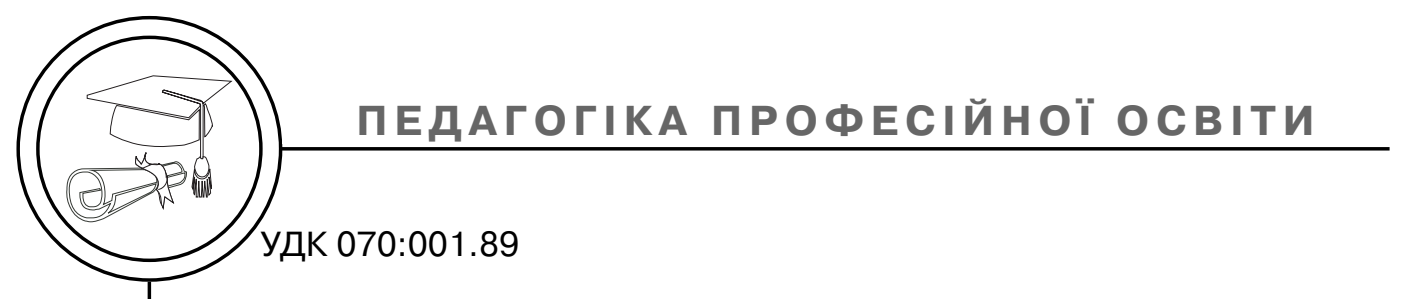

ㅇ І. Л. Побідаш, к.філол.н., доцент, КПІ ім. Ігоря Сікорського, Київ, Україна

\title{
МІЖНАРОДНА КОНФЕРЕНЦІЯ «НАУКОВА ШКОЛА РОМАНА ІВАНЧЕНКА»
}

\begin{abstract}
У статті йдеться про Міжнародну конференцію «Наукова школа Романа Іванченка", ії завдання, учасників, секції, рубрики, плани на майбутнє. Закцентовано на потребі подібних наукових заходів для вищого навчального закладу загалом, а також студентської молоді зокрема.
\end{abstract}

Ключові слова: конференція; Р. Іванченко; кафедра видавничої справи та редагування; видавничополіграфічний інститут; редагування; видавнича справа.

Роман Григорович Іванченко очільник кафедри видавничої справи та редагування Видавничо-поліграфічного інституту НТУУ «КПІ» протягом 1989-2004 років; засновник Київської наукової школи з теорії і практики літературного редагування (визначив її засади, оформив напрями досліджень); автор монографій «Рукопис у редактора» (1967), «Літературне редагування» (1970, 1982, 2003), лекцій, випущених окремими виданнями, «Робота редактора над точністю слова і стислістю викладу», «Мовний штамп в літературній практиці» (1965), «Адекватність розуміння і ясність тексту» (1991), а також багатьох публікацій різних жанрів і тематики; співробітник кількох київських видавництв; один із авторського складу документально-довідкових видань «Історії міст і сіл Української РСР» та «Шевченківського словника», удостоєних Державних премій;

(C) $2017 \mathrm{p}$. заступник головного редактора і член редколегії фахового часопису «Друкарство».

Серед його наукових зацікавлень були літературознавство й текстологія, теорія літературного редагування і становлення редакційно-видавничої справи в Україні; історія започаткування українських видавництв і періодичних видань, видатні персоналії українського друкарства, становлення різних видів видань (від довідкових та інформаційних до рекламних, від популярних до наукових, у тому числі вузькоспеціалізованих), традиції і новації в галузі підготовки фахівців видавничої справи та редагування [1, С. 167].

Світла пам'ять про видатного вченого живе в серцях його колег та наукової молоді. Він як вчений, наставник, педагог, особистість $€$ прикладом для викладачів та студентів Видавничо-поліграфічного інституту.

Цьогоріч вкотре на кафедрі видавничої справи та редагування відбулася конференція «Нау- 
кова школа Романа Іванченка», метою якої $€$ обговорення актуальних фахових питань, дискусії щодо професійної та педагогічної проблематики, плекання наукової молоді. Співголови комітету - професор, д.т.н. Т. Киричок, професор, д.н. із соц. комунікацій О. Тріщук. Організаційний комітет конференції - І. Побідаш, О. Головко, С. Фіялка, Н. Фіголь, А. Литвин, О. Янішевський.

Історія конференції починається 2005 року. Тоді науково-практична конференція до 75-ї річниці з дня народження Р. Г. Іванченка мала назву «Обрії друкарства», на ній було оприлюднено 25 доповідей.

Перша Всеукраїнська конференція під назвою «Наукова школа Романа Іванченка» відбулася 26 листопада 2009 року з нагоди 80-річчя з дня народження Р. Г. Іванченка і об'єднала понад (символічно!) 80 учасників. На ній відбулася важлива подія для Видавничо-поліграфічного інституту, кафедри видавничої справи та редагування, а також усієї фахової громади України - презентація книги «Лицар мови української Роман Іванченко» [2].

За останні три роки (2014, 2015, 2016 років) конференція набула статусу Міжнародної. Ї̈̈ відвідали не тільки українські науковці, а й закордонні, зокрема з Німеччини (Університет Вупперталь), Польщі (Лодзинський університет), Білорусії (Могильовський інститут міністерства внутрішніх справ Республіки Білорусь).

Українська ж наукова мапа за ці чотири конференції складається 3 представників таких навчальних та наукових закладів:
Академія праці і соціальних відносин Федерації профспілок України, Бердянський державний педагогічний університет, Видавничо-поліграфічний комплекс «Політехніка» НТУУ «КПІ ім. Ігоря Сікорського», Державний музей іграшки, Дніпропетровський національний університет ім. Олеся Гончара, Житомирський національний університет ім. І. Франка, Інститут вищої освіти АПН, Інститут мовознавства ім. О. О. Потебні, Київський національний університет імені Тараса Шевченка, Київський національний університет культури і мистецтва, Київський національний університет театру, кіно і телебачення ім. І. КарпенкаКарого, Класичний приватний університет (м. Запоріжжя), Луганський національний університет ім. Т. Шевченка, Львівський національний університет ім. І. Франка, Маріупольський державний університет, Міжнародний економіко-гуманітарний університет імені Академіка C. Дем'янчука, Національний технічний університет України «Київський політехнічний інститут імені Ігоря Сікорського», Одеський національний університет ім. І. Мечнікова, Східноєвропейський національний університет імені Лесі Українки, Ужгородський національний університет, Українська академія друкарства, Український католицький університет, Університет «Україна», Черкаський національний університет ім. Б. Хмельницького, Черкаський державний технологічний університет.

Усього конференцію відвідали науковці з 30 вищих навчальних закладів та наукових установ. 
Окрім докторів та кандидатів наук, викладачів, наукові доповіді на конференції виголошували аспіранти, магістри, бакалаври.

Щорічно конференції під знаком пам'яті про великого науковця Р. Г. Іванченка мають присвяти та тематичні круглі столи, наприклад 2014 року конференція була присвячена 60-річчю Видавничо-поліграфічного інституту та 55-річчю видавничої справи та редагування; 2016 року на честь святкування ювілейних дат І. Я. Франка була виокремлена секція «Іван Франко: редактор, видавець, публіцист».

Секції конференції охоплюють історію та теорію видавничої справи та редагування, актуальні проблеми українського книговидання, культури видання, реклами та PR-комунікації у поліграфії, видавництві та книгорозповсюдженні, персоналії українського книговидання, особливості масової сучасної комунікації, новітні технології в підготовці медійних продуктів, редагування різних видів видань, питання освіти майбутніх редакторів, журналістів, медівників тощо.

За результатами конференції видаються науково-практичні матеріали, паперові та в електронному виданні.

Під час проведення наукового заходу традиційною стала рубрика «Гість конференції». Так, 2015 року конференцію відвідали українські письменники та публіцисти Володимир Арєнєв і Олег Сілін. Говорили про книговидання в Україні та за кордоном, порівнювали промоційні заходи, форуми, фестивалі, аналізували розвиток видання фантастики в Україні, а також по- рушили проблему мотивації сучасної людини до читання. 2016 року гостем конференції став Ростислав Семків - перекладач, літературознавець, літературний критик, виконувач обов'язків директора державного Інституту книги, член журі престижного конкурсу Книга року ВВС, голова видавництва «Смолоскип», доцент Києво-Могилянської академії, - який говорив про сучасний стан видавничого бізнесу в Україні, книжкові форуми, виставки, ярмарки, видавничополіграфічну промисловість.

Кожне сесійне засідання завершується «компліментом» від фольклорно-театральної студії кафедри видавничої справи та редагування «КВАРТFОЛК», який присвячений певній визначній події року (наприклад, ювілейні дати Т. Шевченка, І. Франка, видатних фольклористів тощо).

У планах конференції залучати більше учасників з України та інших країн для наукової комунікації. Проведення в межах конференції майстер-класів, практичних занять, круглих столів, дискусійних батлів, розширення культурної програми та удосконалення промоційних заходів.

Варто зазначити, що до багатьох ініціатив конференції, організаційних турбот активно залучається студентська молодь кафедри видавничої справи та редагування.

Такі заходи як наукові конференції, наукові симпозіуми, круглі столи $є$ важливим компонентом у житті вищого навчального закладу. Вони виконують комунікативну, гносеологічну, інформативну, виховну, організаційну тощо функції. $€$ механізмом 
передачі досвіду, наукових знань, традицій шкіл та формування наукового майбуття навчального закладу. Розуміючи це, кафедра видавничої справи та редагування вже планує, розробляє студентську конференцію в межах кафедри/факультету і відкрита до співпраці та нових ідей.

Отже, конференція «Наукова школа Романа Іванченка» - потужний засіб науково-педагогічної комунікації як в межах кафедри видавничої справи та редагування Видавничо-поліграфічного інституту КПІ ім. Ігоря Сікорського, так і в галузі редагування та видавничої справи. Під час конференції, обговорюючи, систематизуючи, узагаль- нюючи матеріали, наукові висновки та результати досліджень, формується щоразу коло однодумців, породжуються нові ідеї, проекти, міждисциплінарні задуми тощо. Конференція характеризується актуальністю, інформативністю, дискусійністю, творчою співпрацею тощо, популяризує нові ідеї, знання, відкриття в галузі.

Важливим у форматі конференції $€$ співпраця старшого наукового покоління з талановитою молоддю (робота студентів над науковими статтями під керівництвом докторів та кандидатів наук; виступи студентів, аспірантів перед авторитетною аудиторією), обмін досвідом, «майстер-класи».

\section{Список використаної літератури}

1. Хоню В. В. Пам'яті Романа Григоровича Іванченка / В. В. Хоню // Технологія і техніка друкарства. - 2004. - № 4. - С. 166-170.

2. Лицар мови української : Роман Іванченко. Спогади про вчителя, вченого, друга / Упоряд. Г. П. Іванченко. - Київ : Парламентське видавництво, 2008. $-280 \mathrm{c}$.

\section{References}

1. Khoniu, V. V. (2004). Pam'iati Romana Hryhorovycha Ivanchenka [In memory of Ivanchenko Roman Hryhorovych]. Journal of Tekhnolohiia i tekhnika drukarstva - Technology and Technique of Typography, 4, 166-170 [in Ukrainian].

2. Ivanchenko, H. P. (2008). Lytsar movy ukrainskoi: Roman Ivanchenko. Spohady pro vchytelia, vchenoho, druha [Knight of Ukrainian language: Roman Ivanchenko. Memories of a teacher, scholar, friend]. Kyiv: Parlamentske vydavnytstvo [in Ukrainian].

В статье говориться о Международной конференции «Научная школа Романа Иванченка», ее задачи, участников, секции, рубрики, планы на будущее. Подчеркнута необходимость подобных научных мероприятий для высшего учебного заведения в общем, а также студенческой молодежи в частности. 
Ключевые слова: конференция; Р. Иванченко; кафедра издательского дела и редактирования; издательско-полиграфический институт; редактирование; издательское дело.

The article refers to the International conference 'Scientific School Roman Ivanchenko', its objectives, participants, sections, headings, plans for the future. The need for such research facilities for the university in general, and for the students in particular is accented.

Keywords: conference; R. Ivanchenko; Department of Publishing and Editing; Publishing and Printing Institute; editing; publishing.

Рецензент - Т. Г. Файчук, к.філол.н., ст. науковий співробітник Інституту мовознавства ім. О. Потебні 